\title{
Vietnam's Economic History: The Feudalism System
}

\author{
Quan-Hoang Vuong
}

Stratfor World View

Jun 21, 2011 | 05:00 GMT

*Source: https://worldview.stratfor.com/article/vietnams-economic-historyfeudalism-system 


\section{Vietnam's Economic History: The Feudalism System}

We need a few words on the economic system and structure of the country before the sea change brought about by French colonialists could be fully appreciated in terms of economic performance and social context. Generally speaking, until early Xth century, Vietnam-with many name variants adopted by various feudalist kings-had been most of the time under the Chinese domination, approximately 1053 years.

The first domination was happening from 207 B.C. to 29 A.D. A brief independent period followed with the coronation of female sister kings Trung Trac, Trung Nhi, which ended in 43 A.D. The second Chinese domination was the period from 43-544 A.D. The coronation of Lý Nam Đế had gained the control of Vietnam from the Chinese hands for about 60-year Vietnam before the third Chinese domination, 603-907 A.D. Historians tell us that the slavery regime was still prevalent in Vietnam in around 900 A.D.[1] Hanoi, the then called Dai La, was desribed to have been a populated and thriving urban area since end of IXth century. Its residents and merchants traded silk, ivory, gold, silver, paddy rice and other agro-products.

Besides fairly developed horticulture, artisans of the urban Dai La were also able to master important skills for goldsmith, copper casting and molding, iron casting. Literate people of Dai La started using Chinese characters in their writing works-although they were not recorded much by historians but did exist in this period-while merchants could have reasonable access to established market facilities. Economic life of the historical Vietnam would of course have much to deal with the following history of warfares, economic policies by various feudalist governments-particularly those set by the most influential kings-and advancements made by so many ordinary people while pursuing to improve their economic well-being, many of them are now called by modern economic researchers entrepreneurs.

\section{Nascent economy in feudalist society}

Over 25 centuries of its history before the mid-XIXth century, Vietnam's economy had traditionally consisted of agrarian production and micro-scaled handicraft industries. It was almost closed with negligible volume of foreign trade, and most of the time displayed a village-oriented autarky.

The economic life of an independent Vietnam should perhaps started with Lê Hoàn(941-1005)-the founding king of the First Lê Dynasty-who was rising to the kingship during the context of the demise of Đinh Tiên Hoàng and the threat of invasion by the Chinese Song Dynasty in 982. Being a king, Lê Hoàn was interested in developing the local economy and improving people's wealth. He had set himself to be an early example of a king participating in rice cultivating in Spring, right after Tết Holiday, an act that many later kings followed, to show that agricultural economy is very important to all Vietnamese. Also, perhaps in his understanding trade was equally important. He order to build several canals (Ba Hòa Canal to Thanh Hóa, Da Cái Canal to Nghệ An), with which not only farmers could later have a better irrigation system but 
merchants could conveniently develop their transport routes as well.

Under the reign of King Lý Công Uẩn (974-1028)-the founding father of Ly Dynasty, together with Tran and Second Lê, one of the most thriving and prosperous periods of the Vietnamese feudalist history-the capital city was relocated from Hoa Lu (Ninh Bình) back to Đại La, and at the same time, Đại La was renamed to Thăng Long-meaning "dragon flying up." His concern of a new capital city was twin-fold. On the one hand, Thăng Long was in a better position for self-defense purpose with many natural canals, rivers, mountains. The castle had already been well built. On the other hand, economic development would be much easier due to much larger population, skilled labor force, ready-to-use transport systems (by rivers, canals), and much more fertile agricultural lands. The economic reality proved his point positively.

His son, King Lý Thái Tông (1000-1054), added further encouraging policies for economic development such as tax reduction, while trying to remain budget balance and even budget surplus. He enthusiastically encouraged local production by advising people to use local-made handicraft products and even order imperial mades to weave silk and fabrics themselves, so that they would not later have to rely on imports from the Chinese merchants. The fourth king of Lý Nhân Tông (1066-1127)-was highly regarded as the most capable one in all kings of Lý was also the one that further concentrated on improving economic conditions for people to make their livings. He commanded the building of Cổ Xá dyke along the part of Red River flowing through Thăng Long (Hanoi) to protect the capital city from unexpected floods. Killing of buffalos and oxen-used by Viet people for rice field ploughing-was strictly prohibited. He also proactively sought to further develop the market system in Thăng Long, together with transport means for goods. As a consequence of his policies, artisans focused on manufacturing a variety of consumers' goods such as dyestuff, fabrics, paper, copper, furniture, and so on.

Under Trần Dynasty (1225-1400), Thăng Long continued to be an economic and industrial hub, and reached a somewhat higher level of development, perhaps thanks to a reasonably long period of peace and the reputation of a commercial city. Foreign trade then provided more exciting opportunities for both local residents and foreign merchants-mostly Chinese and Ugurian (from Central Asia)-who opened shops for exchanging various consumer's goods. Agriculture also improved with increasing area of cropland gained, which had been reclained by military force and ordinary people, and more agricultural lands were better irrigated. The economic development policies adopted by early Trần's kings inherited the idea formulated by one of the most well-known senior general of Vietnam's history-Trần Thủ Độ-who had decided to bolster the economic development of the capital city by more economic reform so that savings and wealth could help contribute to a bolstered military force. The Trần Dynasty was best known for its three triumphant defeats of the formidable and mighty arm forces of the Mongols-in 1258, 1285 and 1288-which had swept through many Asian and European borders in XIIIth century.[2]

In an early modern history book, Việt Nam Sư Lươc, one could see clearly that throughout the history,[3] Vietnam's economic activities had been rarely mentioned and clearly poorly documented. However, it did mention that gold had been used as money, with unit being a tael. Each tael could be exchanged for 70 quan-the formal coin minted and circulated by the Trần Dynasty in the first half of the XIIIth century (from 1225-1253).[4] The currency was then used 
to pay personal tax, one quan per head each year. Nonetheless, the most imporant tax should arguably come from farming production, mostly levied paddy rice fields, and was actually paid in rice. There existed many other type of taxes, such as for production of salt, fish, vegetable, and many other consumers goods alike. Being engaged in series of border wars with its southern neighbor, Champa, Trần Dynasty did at times showed its military strength, supported by economic wealth, and gradually implemented a southward expansion. Given the economic prosperity in some substantial periods under the reign of Trần, substantial cultural progress also emerged. Nôm scripts were invented and used in the first place in XIIIth century under Trần Nhân Tông (1258-1308). The first history work which was ever written in Vietnam was finished in 1272, Dai Viet Su Ky Toan Thu by the eminent historian Lê Văn Hưu. In this period, we could see that economic development served as the main propeller for overall development of the society, as well as the country's territorial expansion.

When Hồ Dynasty (1400-1407) usurped the throne from the Trần, Hồ Quý Ly also implemented some economic changes, including unifying the weight and volume measure system, improving river-transporting means, establishing administrative system for collecting taxes and fees from merchants, building foodstuff reserve to intervene when market rice prices fluctuating too much, etc. Like previous kings of Trần, he perhaps pursued an improved government budget and arms force. Historians cited reasons of his failures in these reforms as being implemented in very short timeframe and conflict of interests with aristorats (owners of wealth), merchants, hence urban artisans.

It is noteworthy that a majority of collected taxes and fees by the feudalist central governments in Vietnam's history were used for unproductive reasons, mostly warfare preparation (viz. weapons, military foodstuff reserves), kings' residential palaces, and aristoratic class luxury goods (to their standards). Rarely useful spending was documented for instance dyke building to prevent cropland flood, frequently occuring in the Red River Delta causing famine and starvation of farmers. Taxes were heavy financial burden that ordinary people had to accept. In narrative by historians, tax reduction is always the best thing a king could do to his people, and that is only done a few years after his coronation, then short-lived. Another important economic policy of several good kings is to grant land (including fertile cropland) to the poor people. One typical example is the case of Lê Thái Tổ (1385-1433), the first King of the Second Lê Dynasty coronated in 1428, who redistributed land to not only his subordinates, serving him during the 10-year war with the Ming Dynasty's troops. Supplying foods and foodstuffs to the army is clearly also a very challenging task. Lê Thái Tổ, when engaged in fighting against the Ming's troops, had an army of 250,000. After his victory, the Lê Dynasty still kept 100,000 with the army. Taxpayers, mostly proletarians, were greatly exploited by aristorats and kings through various kinds of tax and fees to maintain military forces for the powerful feudalist bloodlines.

The third king of the Second Lê reigns, viz. Lê Thánh Tông (1449-1497), proved himself one of the most talented feudalist leaders in the entire history of Vietnam, who we should not overlook fruitful socio-economic policies and their implications towards the development of entrepreneurship in a rare prosperous moment of such a war-ridden evolution. First, he did not forget to reassure Viet farmers about his economic policies that favored agricultural production. He implemented a set of measures which had been devised to encourage farmers to actively improve both farming techniques and work hours, and to exploit 
unused lands for cultivation, expanding farm lands further to jungles in the rural areas of his kingdom. But his policies also reflected an adequate concern of and a forward-looking view towards developing a better and thriving commercial urban city Thăng Long (viz. the capital city in his time, and today's Hanoi).[5] He paid substantial attentions and made incessant efforts to encourage trade activities, to significantly improve road and river transportation, to establish many new markets as well as new ports along major rivers and at important coastal areas. We could by no means deny the causal nexus between the boom of trade activities and domestic manufacturing capacity, which in our very modern theories would induce each other, especially when growth is on upswing. Clearly his situation, positive effects brought about by Lê Thánh Tông's economic policies were further bolstered with help of a reasonably long period of peace.

This king was going even further in his decisive promotion of economic growth by re-planning the then-largest urban area of Thăng Long to conceptually consist of 36 trading streets, each was somewhat specialized in a specific categories of related goods. It is interestingly enough for us to see that today Hanoi could still be referred to as "36 Phố Phưòng"-viz. the city of 36 trading streets-without ambiguity to any Vietnamese of the modern day. Thus, his vision was really beyond many think-tanks of his time. Not long after this, his economic plan and policies started flowering. Artisan-residents and skilled workers from outside then poured their investments in Thăng Long, hence further attracting more merchants from different places, in seeking entrepreneurial opportunities in a promising land. What we learn from this period is apparently the boom of entrepreneurship, commerce, manufacturing techniques and transportation all at the same time, in the same place. Things that are worthwhile even today were then high quality silk, embroidery, and embroidered cloths, hand-made jewelry, furniture, copper appliances, leather products, casting technique, printing services, etc. A major weakness of the economy under his reign was inadequate activity of foreign trade.

However, that is something he could not solve by himself although his pursuit of trade and economic development was earnest and whole-hearted. But even with the weakness of foreign trade under the Lê Dynasty, Lê Thánh Tông was still able to maintain a very busy foreign trade port of Vân Đồn, one of the five major ports in the entire premodern history of the country. His economic policies really boosted entrepreneurial engagements by so many urban residents and farmers. In this kind of thriving society, it is not surprising that general level of an average person's well-being displayed a significant improvement compared to many previous societies, and perhaps also many subsequent ones. The general degree of development also improved in other aspects such as cultural and scientific.[6] We do not have chance to see many periods of entrepreneurship efflorescence as such. Generally speaking, there existed little economic data and detailed information on economic activities conducted over this long period of history, thus making our approach of considering the overall evolution from a socio-cultural analysis the only choice to take.

At the end of XVIth century, the country was again moving into a long period that witnessed a series of brutal civil wars, from 1627 to 1672 , between two major noble bloodlines, Lord Trịnh and Lord Nguyễn. They both had many members of the family holding high-ranks in the Second Lê Dynasty. In fact, these two Lords had firm grips of power of the whole country, thus de facto 
divided it into the North and the South, with Trịnh controling the North and Nguyên the South, putting the King of Lê then in a powerless position only. These two political powers remained in high hostility for a long period of 150 years, from 1627 to 1777 .

In the South (usually referred to as Đàng Trong), foreign trade started to emerge in early XVIIth century, with Portugese traders being first foreign businesspeople coming first to Hoi An port town near Đà Nẵng, almost the same period when the Dutch occupied Java islands of today's Indonesia in 1594.[7] It was said that Jean de la Croix was the first Portugese to have established a cannon molding mill-perhaps a lucrative business operation-in Thuận Hóa town, near Hue in the central region in 1614.[8] The French arrived in Hội An port city in 1686. More importantly, French ship Machault embarked on Hội An in 1749 and presented a letter proposing first formal diplomatic relationship with Lord Nguyên, which received his warm regard.

In the North, the presence of Portugese ships and sailors were noticed also in early XVIIth century. Gradually a commercial town in today's Hưng Yên Province, called Phố Yên, emerged firstly with trading shops owned by Dutch traders in 1637. This town for a period become the commercial hub in the North with exciting trading opportunities for both local and foreign traders. Following Portugese and Dutch businessmen, many Japanese, Chinese, Siamese (Thai) tradesmen arrived and set up commercial operation in this town, making it the second most important urban areas in the North, only after Thăng Long. That town at the peak of its flourishing business season had over 2,000 shops in a small area-a high density of business activities. The boom of trade in Vietnam this time even led to the first attempt of romanization of Vietnamese language by Alexandre de Rhodes (1591-1660)-the French Roman Catholic missionary and scholar living in the East Indies in this period, circa 1627-evidenced by his publication Dictionarium Annamiticum Lusitanum et Latinum (viz. Vietnamese - Latin - Portuguese Dictionary), published in Rome in 1651. 


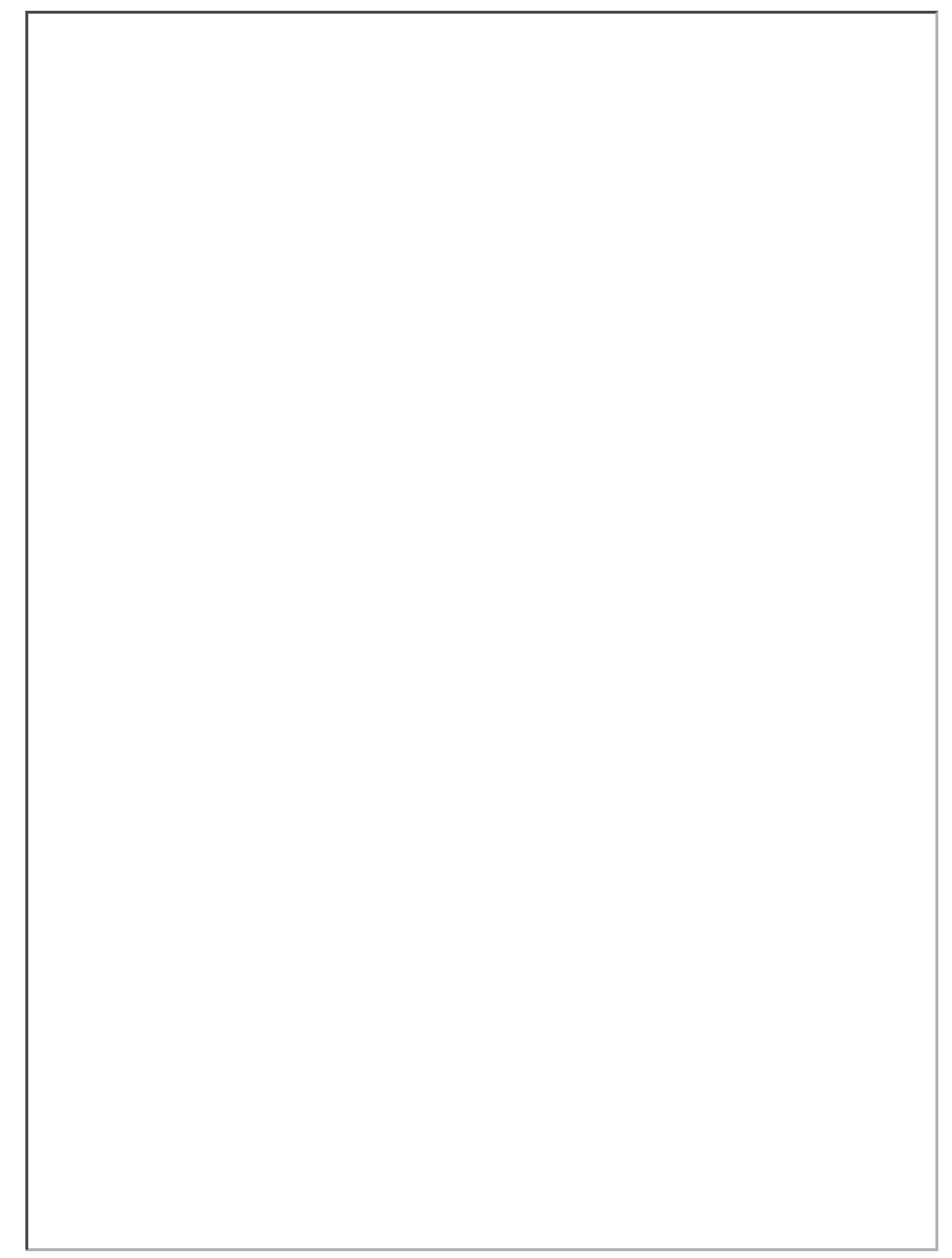

Alexandre de Rhodes's dictionary, 1651 | Source: Wikipedia.org

\section{Why early foreign trade gone?}

In terms of money, Japanese trade coins were circulated or were melted to make utensils as well. Alexandre de Rhodes said in his book that the current coin in the North consisted of large copper coin brought in from Japan and small coin minted locally. Large coins were circulated everywhere, but small coins were used only in the capital and four surrounding districts. The value of the local coin varied depending on the quantities of great cash brought in each year but was normally priced at 10 small cash to 6 large cash (Alexandre de Rhodes, Histoire de royaume de Tunquin, Lyon, 1651).

Some details in the Register of the British East India Company showed the busy activity of coin trade in Phố Hiến as follows.

Coin Trade in Phố Hiến, 1672-1676

August 22, 1672: 3 Dutch ships arrived from Batavia bringing 6 millions; Japanese cash and 1000 tael of silver

April 7, 1675: 1 Chinese junk arrived from Japan with copper cash and silver June 17, 1675: 1 Dutch ship arrived from Batavia with 80 chests of Japanese cash

February 23, 1676: 2 Chinese junks arrived from Japan to bring silver and cash

English traders also came to do business in Vietnam in 1672 or so, with the first ship Zant visiting and asking for licence of the first shop in Phố Hiến. They ceased to do trading here because the profit was not as expected and left in 
1697. The French came in town in 1680, followed by the French ship Saint Joseph in 1682. Trading activity in the North (Đàng Ngoài)saw a sharp decline when Dutch businessmen stopped their operation in 1700. Foreign trade was further weakened by increasing religious conflicts between both Lord Trịnh and Lord Nguyễn with Roman Catholic missionaries and followers delivering their religious teachings in both Đàng Ngoài and Đàng Trong. After 1700, not much about trade with foreign businessmen was documented by historians, giving us a tacit understanding that the first 90-year efflorescence of foreign trade stopped by early XVIIIth century. Even with the most optimistic mind, we could not assume that this trade boom to have continued beyond 1750 since Vietnam, already divided by Nguyễn and Trịnh, was now engaged in a new long period of civil war among Trịnh, Nguyễn bloodlines and the rising Tây Sơn-which started gathering military strength from 1771-sometimes interfered by foreign military powers, namely the Siamese (1782-1785) and the Chinese Qing (1789). Nguyễn Huệ, later becoming King of the Nguyễn Tây Sơn Dynasty in 1788, defeated Siamese naval troops in 1785 and the Qing army, whose military assistances had been invited by Nguyễn Ánh and the last King of Lê Dynasty-Lê Chiêu Thốngin 1789. The Nguyễn Tây Sơn Dynasty lasted for only 14 years, put to an end by the rise to kingship of Lord Nguyễn Ânh in 1802.

\section{Industry in Nguyễn Tây Sơn}

In most works, when writing this part of the history, Vietnamese historians usually extol Quang Trung Nguyễn Huệ of the Tây Sơn with flowery words on his brilliant military victories over Siamese and Qing invading forces. Nonetheless, from the economic view, he did not perform well since being engaged in non-stop military battles no real effort was made for reconstructing the economy in bad shape, or at least no words were found writing about any measures of boosting trades, agricultural production or industrial manufacturing. Meanwhile, Nguyễn Ánh (1777-1820) the male heir of the powerful lords of Nguyễn in Đàng Trong who had been orphaned by the Tây Son Nguyễn brothers, nurtured his plan to come back in power, then quietly returned to the South coastal provinces. He made a wise move of encouraging economic activities, especially farming and expanding cropland. Soldiers were also requested to participate in crop harvest. His economic policy on trade was also purposeful. To have sufficient funds to purchase metals and explosives, foreign merchants were encouraged to trade in his territories. Trades were performed on arm's-length basis using market price. Domestic merchants were allowed to barter-trade with foreigners for weapons and military materials.

When Nguyễn Ánh took power in 1802, after the death of Quang Trung Nguyễn Huệ and the rupture of Tây Sơn Dynasty's military muscles, he employed a number of appropriate economic policies, namely clear stipulation of tax system, tax reduction for regions facing difficulty such as natural catastrophe, low agricultural yield, draught, etc. Minting coins was organized with clear rules and monitored closely by the government. In monetary term, one tael of gold was in exchange of 10 taels of silver. Where appropriate and necessary, the government established new coin-minting mill, ensuring the adequacy of money for trade and economic activity. Apart from silver and gold coins, lowervalue coins were also minted by the government, consisting of copper and zinc coins from 1803, viz. his second year as king. The government also stipulated the weight measure systems to facilitate trade. In addition, roads were repaired or built new. Dykes and irrigation systems were renovated and protected to facilitate agricultural production. Rice reserves were built in many towns so that in emergency, the government could supply foods to people in time. 
Persistant states and detrimental impacts of feudalist warfares are the main characteristic of this 2,500-year part of Vietnam's premodern history. Stable economic development could hardly be attained even in the seventeenth century when trades became more active and economic conditions improved briefly in temporary peace. In pecuniary terms, both governments of Đàng Ngoài and Đàng Trong performed poorly, with persistent budget deficitalthough not very serious-in mid-seventeenth century (1746-1753). Trades, usually a precursor to any prosperous society, almost disappeared in this period, and reappeared only sporadically. Towards the end of this period, it was fortunate that King Gia Long Nguyễn Ánh now displayed a set of "fairly" efficient economic policies which helped restore the economic conditions in part, although we have not had sufficient statistics to make an appraisal on the actuall output improvement under the reign of Gia Long.

However, after King Gia Long, the Nguyễn Dynasty was not able to hold firm grip of power for long. Military conflicts with French soon turned out escalated wars in all major regions and led to French protectorate agreements, a starting point for the next 80 years of the French colonization. It is not unexpected that no major economic progress was documented for this period.

* Related: A Brief Introduction of the History of Vietnamese Economy

* Notes:

[1] Dang Duy Phuc (2006) Giản Yếu Sủ Việt Nam, Hanoi Publisher, Vietnam. [2] After the first Tran Dynasty's defeat of the Mongols, the world's most mighty army in the XIIIth century led by Koubilai-a grandson to Gengis Khan, in 1258, a newly coronated King of Trần Dynasty, Trần Thánh Tông ordered homeless and poor Viet people to go reclaining waste and virgin soil in various delta areas in the North, expanding the cropland for farmers.

[3] Trần Trọng Kim, 2002(1919), Việt Nam Sư Lược, NXB Van Hoa Thong Tin, Hanoi

[4] Tael is a Chinese jewelry measure, which is still used widely in the present day in Vietnam, equivalent to 37.5 grams. We have no clue whether the tael described in Tran $\{2002,1919\}$ is the same measure as that of that present. [5] In reality, economic impacts of his effort was not only limited to Thăng Long, but it was this city that could exemplify spectacular symbol of development and had its momentum of prosperity carrying on over many decades after his demise.

[6] It is also not by chance that under this king, in a prosperous economic setting, some first scientific achievements were reached. For the first time ever in the country's long Confucian educational system, which was infamous for being against innovation and loyal to old teachings, two famous mathematicians became known to the public; they were Lương Thế Vinh and Vũ Hữu-both were awarded title Nghè, an equivalent doctorate as defined by the Confucian scholarly examining system-who later made major contributions to calculus and mathematical applications in the society. These works are Đại Thành Toán Pháp and Củu Chuoong Toán Pháp by Lương Thế Vinh, and Lập Thành Toán Pháp and Phép Đo Đạc Ruộng Đất by Vũ Hữu.

[7] The Portugese occupied Macau in 1563 while the Spanish colonized the Phillipine islands in 1568.

[8] In 1631, Lord Nguyễn Phúc Nguyên (Sãi) also established a special cannon molding mill, probably inspired by the idea of de la Croix and obsessed with prospect of possessing a mighty arm force in the context of persistent TrịnhNguyễn military conflict. 